\title{
Infiltration rate performance of buildings in the historic centre of Oporto
}

\section{Evaluación de la tasa de infiltraciones de aire en edificios del centro histórico de Oporto}

$\underline{\text { S. Alves }}^{(*)}$, J. Fernández-Agüera ${ }^{(* *)}$, J.J. Sendra ${ }^{(* *)}$

\begin{abstract}
This work is part of a major investigation the authors are undertaking aiming to evaluate the energy performance of different retrofitting strategies for housing buildings, in order to establish preferential criteria of intervention according to its climate zone location, morphology, constructive features and patrimonial values. In the historic centre of Oporto, one of the major actions resides on a significant reduction in the heating loads of these distinctive buildings by decreasing the windows infiltration rate. To be able to accurate this potential for energy savings, in situ measurements of the infiltration rate of this houses at present were required, previous to a possible intervention. This article presents the data obtained using a fan pressurization method in two non-refurbished characteristic buildings of the Oporto's Historic Centre, and analyses the results obtained for both a typical sash window and a casement window. Some relations between these infiltration rates and the buildings morphological and typological characteristics are considered.
\end{abstract}

Keywords: Building retrofitting; historic centres; air infiltration rate; fan pressurization method; energy efficiency.

\section{RESUMEN}

Este trabajo forma parte de una investigación mayor que los autores están llevando a cabo y que tiene como objetivo evaluar la eficiencia energética de diferentes estrategias de rehabilitación de edificios de viviendas, con el fin de establecer criterios preferenciales de intervención de acuerdo a la zona climáticas donde se ubica, a la morfología de los edificios, a sus características constructivas y a sus valores patrimoniales. En el centro histórico de Oporto, una de las principales acciones consistiría en la reducción significativa de la demanda de calefacción en los edificios de viviendas que lo caracterizan, mediante la disminución de la tasa de infiltración de las ventanas. Para poder precisar este potencial de ahorro de energía, se requieren mediciones in situ de las tasas de infiltración de las citadas viviendas en su estado actual, previamente a una posible intervención. En este artículo se presenta los resultados obtenidos en los ensayos de presurización llevados a cabo en dos edificios característicos del Centro Histórico de Oporto que no han sido objeto aún de rehabilitación, y se analizan los valores alcanzados para ventanas típicas de guillotina y abatibles. Además, se estudian las relaciones entre los valores de estas tasas y las características morfológicas y tipológicas de los edificios.

Palabras clave: Rehabilitación; centros históricos; tasa de infiltración de aire; método de presurización por ventilador; eficiencia energética.

\footnotetext{
(*) Instituto Superior Manuel Teixeira Gomes (ISMAT). Portimão (Portugal).

${ }^{(* *)}$ Instituto Universitario de Arquitectura y Ciencias de la Construcción (IUACC), ETSA - Universidad de Sevilla (España). Persona de contacto/Corresponding author: silvia_alves2003@yahoo.es (S. Alves).
}

Cómo citar este artículo/Citation: Alves, S., Fernández-Agüera, J., Sendra, J.J. (2014). Infiltration rate performance of buildings in the historic centre of Oporto. Informes de la Construcción, 66(535): e033, doi: http://dx.doi.org/10.3989/ic.13.009.

Licencia/License: Salvo indicación contraria, todos los contenidos de la edición electrónica de Informes de la Construcción se distribuyen bajo una licencia de uso y distribución Creative Commons Reconocimiento no Comercial 3.o. España (cc-by-nc). 


\section{INTRODUCTION AND OBJECTIVES}

Energy efficiency is nowadays one of the major guidelines for all the construction interventions (1) (2). When dealing with retrofitting of historic buildings one must try to join this concept with the buildings morphology, its constructive characteristics and its patrimonial values such as traditional building materials and techniques that should be preserved.

The Historic Centre of Oporto, inscribed as Unesco's World Heritage in 1996 is still characterized by the degradation of its urban built heritage, mostly due to the exit of the current resident population. The last World Heritage Centre's Report (3) refers the need to respect "the pre-existence of values and the character of the historic city", which should determine a both conceptual and operative principle for establishing preferential criteria of retrofitting strategies.

In the specific case of Oporto's historic buildings, one of the main typological attributes to take on account is the façade design and its impact on energy consumption, due to the proportion between exterior walls and windows, as exemplified in Figure 1.

Considering that in Oporto the cooling demand is generally $10 \%$ of the heating demand, also SRU (4) defends that ventilation has a major impact in buildings heating demand and that the renewal of the interior air may be responsible for $30 \%$ to $50 \%$ of the total energy needs in the heating season, which leads to the need to minimize the flow rates to reduce energy consumption.

The Portuguese adaptation of the concepts defined in the European directive related to the energy performance of buildings (5) is established in three documents: the RCCTE (6), the RSECE (7) and the SCE (8).

According to the RCCTE (6), the reference value for the ventilation rate in new buildings is $0.6 \mathrm{ACH}$, and the conventional values to be considered taking on account the air tightness of a non-classified window, may vary between 0.80 to $1.15 \mathrm{ACH}$, reaching $0.88-1.27 \mathrm{ACH}$ when the glazing surface is $15 \%$ superior to the interior floor surface.
As denoted by Alves \& Sendra (9) it is possible to obtain a significant increase of the energy efficiency in the heating loads of Oporto historic buildings when improving the windows infiltration rate. In this investigation, the authors considered three theoretical values for the ACH (Air Changes per Hour). It was established $1.5 \mathrm{ACH}$ as a reasonable value for the air infiltration rate of the windows on its current conditions, an intermediate value of 1.o $\mathrm{ACH}$, and $0.6 \mathrm{ACH}$ as a target level for a retrofitting intervention reference. An energy simulation model of a specific building in the historic centre of Oporto was created using the Design Builder program, which uses the Energy Plus dynamic simulation engine to generate performance data, testing the hygrothermal performance of buildings and its energy demands.

Analysing the results obtained for the heating and cooling loads in the three tests, it was established that with 1.o ACH there was a $\mathbf{2 2 . 7 \%}$ reduction for the heating demand in relation to the value of $1.5 \mathrm{ACH}$, reaching a $42.7 \%$ reduction with the $0.6 \mathrm{ACH}$ simulation.

However, there are no known measurement data that may characterize the air infiltration rate of the buildings in the historic centre of Oporto. The main purpose of this investigation is to determine the ACH of some representative buildings of its original constructive system, by means of in situ measurements. This characterization is a primary measure to take on account in order to to accurate the potential for energy savings when improving the ventilation rate in these buildings. Using a fan pressurization methodology, several dwellings in two non-refurbished characteristic buildings of the Oporto's Historic Centre were measured, focusing the analysis on its morphological characteristics and windows typology.

\section{VENTILATION AND AIR INFILTRATION RATE:}

\section{Parameters and their influence on the energy demand}

Besides the key factors defined by some authors (10) (11) as determinant in the glazing influence on buildings thermal performance such as the Fenestration Factor $(\mathrm{FF}=$ Window

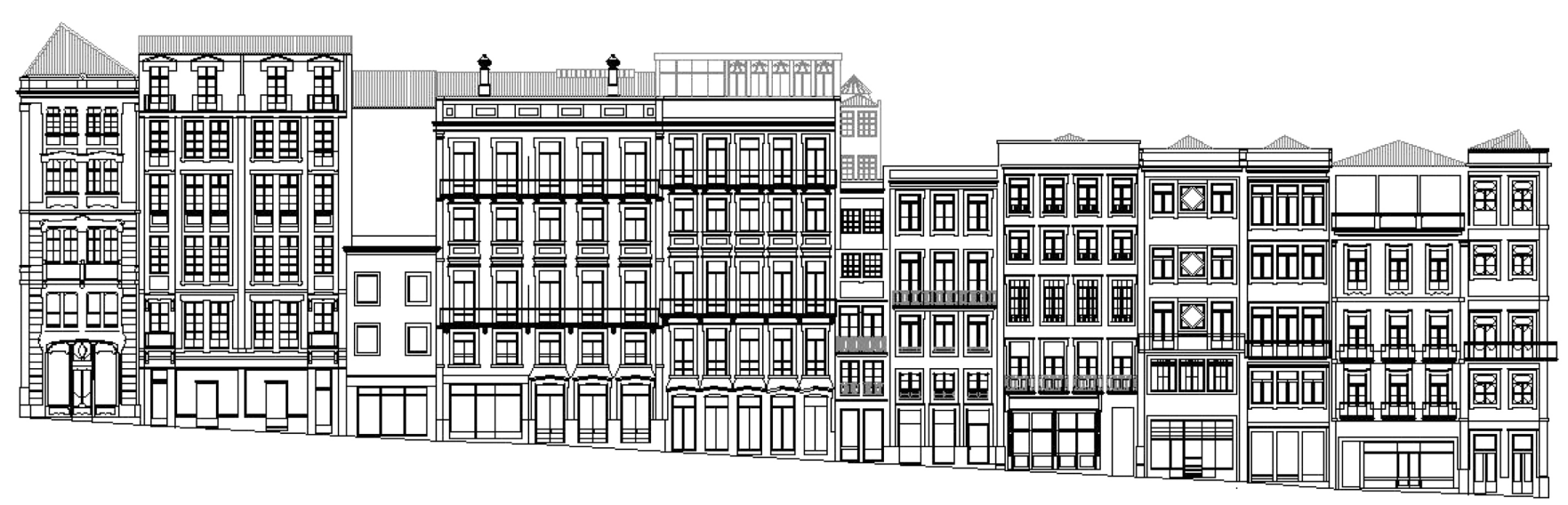

Figure 1. Example of a street façade in Oporto's historic Centre- Rua Mouzinho da Silveira 
area/room area), the Window Wall Ratio (WWR = glazing area/external façade area), and the Effective Aperture (EA $=\mathrm{WWR} \times$ glazing visible transmittance VT), it is also recognized both theoretically or empirically the importance of ventilation and the infiltration rate on the hygrothermal performance of buildings.

When Papadopoulos (12) monitored the thermal comfort conditions of 42 buildings in Greece, the short time air velocity was one of items measured, along with air and surface temperatures and relative humidity. In the larger group of the sample (73.8\%), corresponding to those buildings constructed between 1940-1980, and regarding the total heating demand, it was determined that ventilation and infiltration account for $30.8 \%$ of heat losses, being considered $34.2 \%$ for walls, $\mathbf{1 1 . 2} \%$ for roofs and $\mathbf{2 3 . 7 \%}$ for transmittance losses through openings. In this group only $40 \%$ of the buildings had some kind of insulation on walls and roofs and a few $22 \%$ of the windows had been replaced with double-glazed ones. Comparing to the buildings more insulated erected after 1980 ( $14.3 \%$ of the sample), all the values corresponding to the exterior envelope -walls, roofs and openings- decreased respectively to $29.9 \%, 7.7 \%$ and $21.9 \%$, causing an increased relative value of $40.6 \%$ for ventilation and infiltration. Also Tommerup \& Svendsen (13) and Dominguez et al. (14) defended that the basis for energy-saving measures is the heat loss from different building envelope elements and ventilation. Analysing several buildings constructed between 1930-2003 it was recognizable the "potential in reducing the heat loss through windows and ventilation heat loss is considerable for all buildings, and that they are the largest heat loss contributors in newly built dwellings", mostly due to well-insulated exterior walls after the building codes of 1979. This aspect is also highlighted by Binamu (15) when concluding that air leakages influence heat losses also through their effect on the function of the thermal resistance of insulation materials and that $53 \%$ of the ventilation heating energy in buildings is lost due to uncontrolled air changes.

By varying the air change rate at $50 \mathrm{~Pa}, \mathrm{n}_{50}$, between $1,3,5$ and $10 \mathrm{ACH}$, heating energy consumption may increase from $4 \%$ to $21 \%$ in cold climate areas (16) as well as in US office buildings infiltration may be responsible for about $13 \%$ of the heating loads and $3 \%$ of the cooling loads (17).

Since earlier studies in 1979 (18) the mathematical analysis was used for testing the air tightness of windows by specifying the pressure difference across a window $\Delta \mathrm{p}$ and the limit value of the volume of air leaking through per unit length per unit of time, being this methodology still operative for defining parametric studies of ventilation in a wide range of buildings through a small number of graphs (19).

The standardized Blower Door pressurization technique is nowadays the more currently used methodology in order to determine the air permeability of the building elements in situ (20) (21) (22) (23). Along with other methodologies, several studies have permitted to acknowledge the range of variability in air change rates $(\mathrm{ACH})$ from country to country
(24) and its influence on ventilation efficiency (25). According to the results presented (24) (26), the ventilation rates registered for Portugal varied between a minimum value of $0.5 \mathrm{~h}^{-1}$ and a maximum value of $1.2 \mathrm{~h}^{-1}$.

\section{METHODOLOGY}

\subsection{Characterization of the models}

For this experiment, a late 19th century building (Model M1) located in the historic Centre of Oporto was elected, considering the two windows typologies presented and the access to the interior provided (Figure 2).

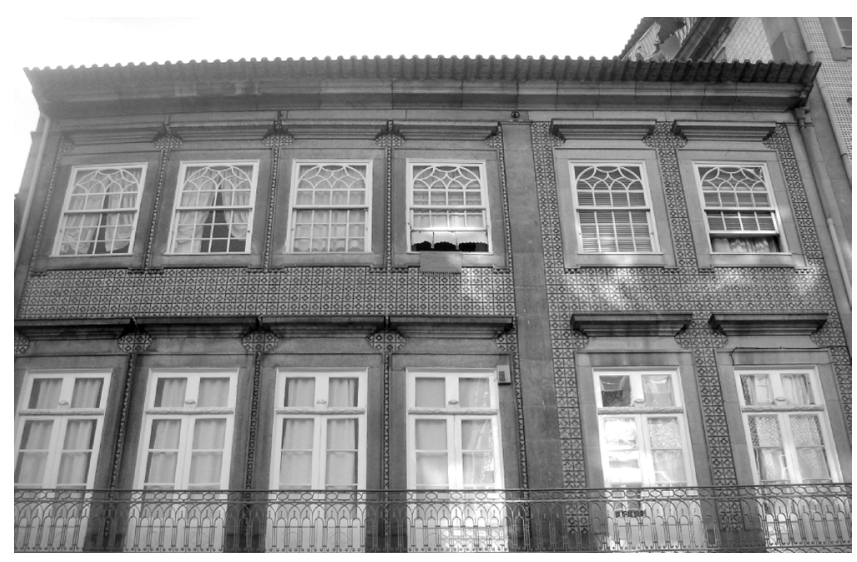

Figure 2. Main street façade of Model M1: First floor - Casement Windows: Cw.1 and Cw.2; Second floor: Sash Windows Sw.3, Sw.4

This building has a main street façade east oriented to Rua Ferreira Borges, with an entrance on No. 57, and a back façade west oriented to an internal block patio. In both floors, that are daily used respectively as offices and residences, the state of conservation of the windows can be considered as the original once they don't present any frame sealing and the single glazing is still installed with plaster. The frames didn't present any apparent cracks.

In Model M1, the first floor (Figure 3) consists of two rooms oriented to the internal block patio (Rooms 1 and 2) both ventilated through a balcony with a whole sash window (Sw.1Balcony 1). Rooms 3 and 4 are main street oriented and present the most common of Oporto casement windows (Cw.1 and Cw.2). Although with independent floor entrances it is a single fraction.

On the second floor (Figure 4) it was accessible Room 5, also ventilated through a balcony with a whole sash window (Sw.2-Balcony 2) and Rooms 6 and 7, both with two sash windows (Sw.3 and Sw.4). Room 7 and the adjacent non accessible dwelling define an independent fraction.

In another 19th century house (Model M2), a single dwelling was also object of in situ measurements, due to a quite different state of conservation and in order to achieve more accurate conclusions. It is inhabited for a long time and both the window frames and the envelope area present quite a few cracks (Figures 5 and 6). This dwelling is south oriented to Rua João das Regras. 


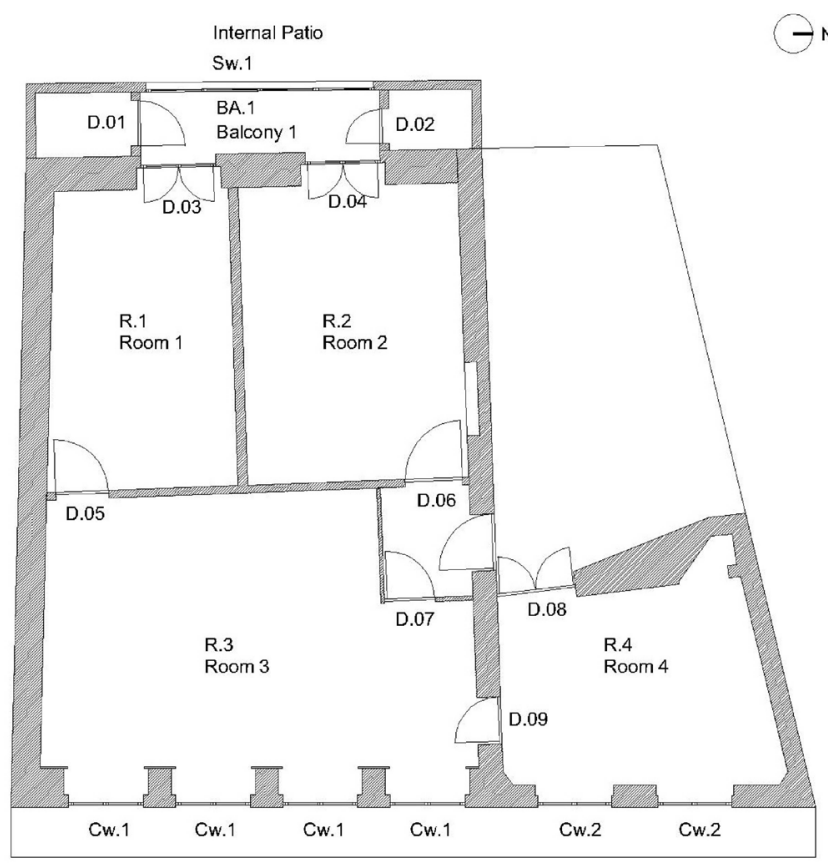

Figure 3. Model M1 - First Floor plan (no scale)

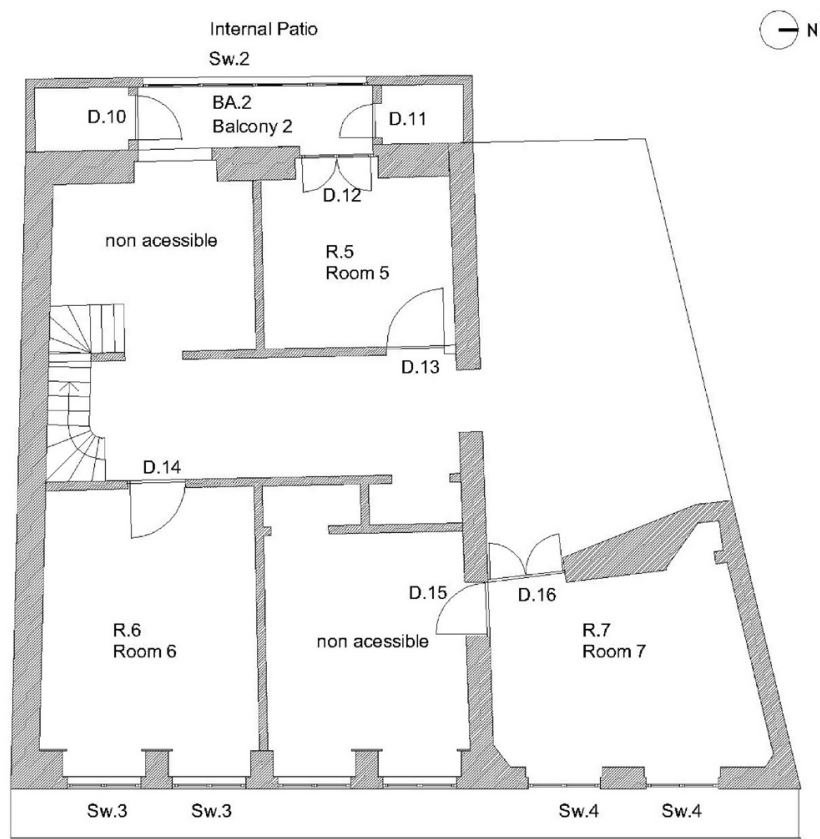

Figure 4. Model M1 - Second Floor plan (no scale)

All the analysed dwellings and respective openings were measured in Models M1 and M2, as presented in Table 1 and Figure 7. Both models didn't present any ventilation system.

Table 1. Morphological characterization of Models M1 and M2

\begin{tabular}{|l|c|c|}
\hline \multicolumn{3}{|c|}{ Difference } \\
\hline Mean (M) - Median & 1.80 & $93 \%$ \\
\hline Mean (M) - Standard Deviation (S) & 15.43 & $40 \%$ \\
\hline
\end{tabular}

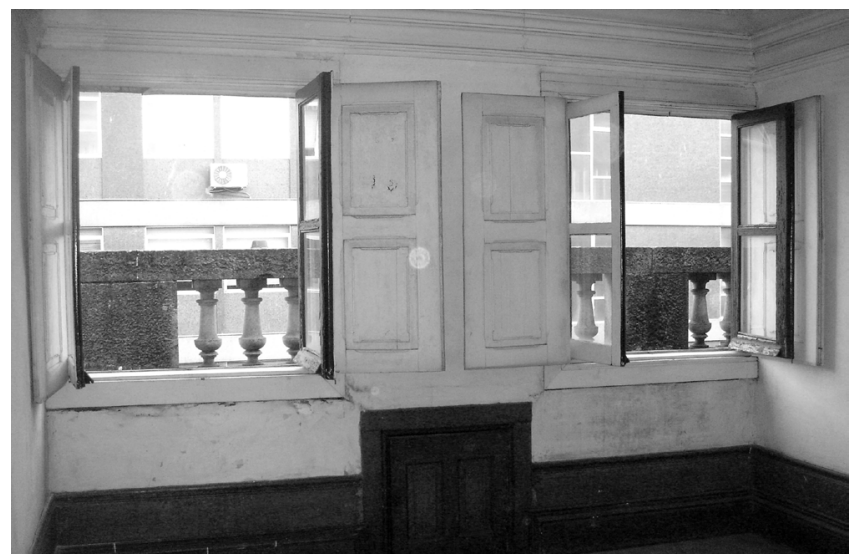

Figure 5. Model M2 - Interior view

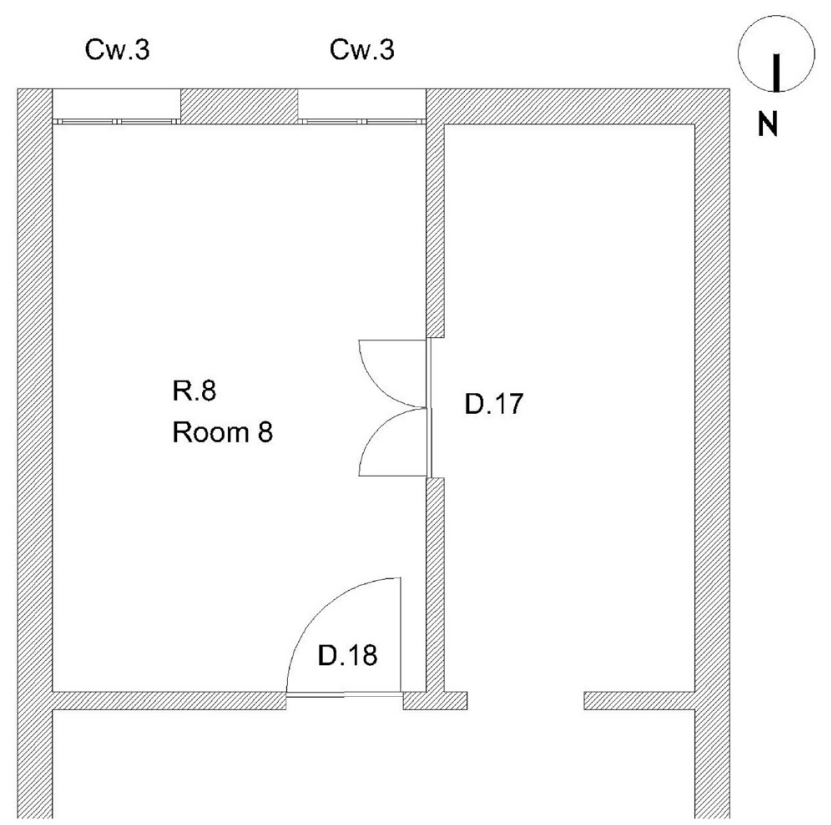

Figure 6. Model M2 - Dwelling plan (no scale)

\subsection{Climate characterization}

The RCCTE (6) defines three climatic zones for winter $\left(\mathrm{I}_{1}, \mathrm{I}_{2}\right.$ e $\left.I_{3}\right)$ and three climatic zones for summer $\left(V_{1}, V_{2}\right.$ e $\left.V_{3}\right)$. The city of Oporto belongs to the " $\mathrm{I}_{2}$ " winter zone and the " $\mathrm{V}$ " summer zone.

The reference values for internal comfort are of $20^{\circ} \mathrm{C}$ for the heating season and $25^{\circ} \mathrm{C}$ and $50 \%$ of relative humidity for the winter season.

The "I2" winter climatic zone is characterized by 1610 degree days and 6.7 months of heating season. The "V1" summer climatic zone considers $30^{\circ} \mathrm{C}$ as a reference for external temperature along with a maximum daily temperature range of $9^{\circ} \mathrm{C}$.

Along with defining the environment conditions to be considered for determining the energy consumption of the buildings, this document (6) also establishes maximum values both for cooling (Nv) and heating loads (Ni). The maximum 
Sw.1; Sw.2

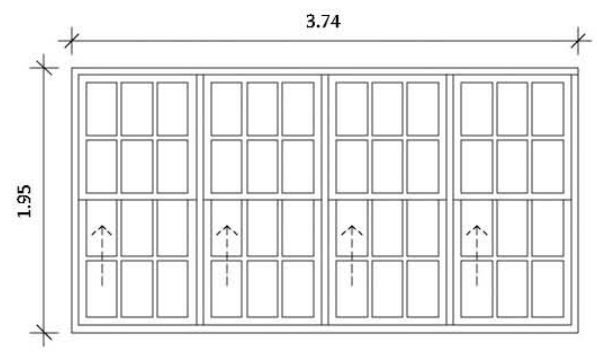

Sw.3; Sw.4

1.18

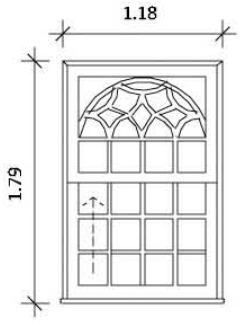

Cw.1; Cw.2

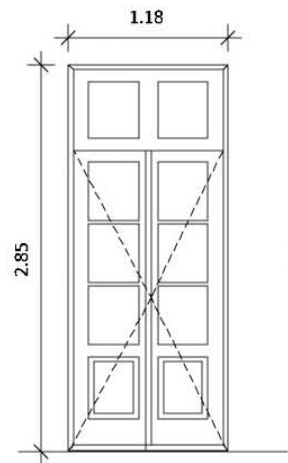

D.04; D.12

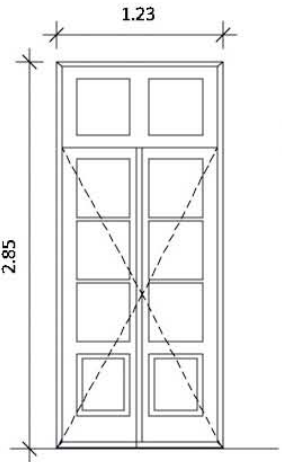

Cw.3

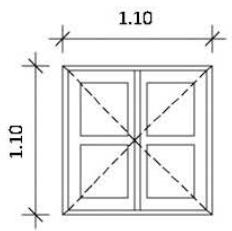

Figure 7. Openings morphology of Models M1 and M2

value for the cooling loads is a variable established for each climatic zone, being for Oporto of $16 \mathrm{kWh} / \mathrm{m}^{2} y e a r$. The maximum value for the heating loads in Oporto varies from 68.10 $\mathrm{kWh} / \mathrm{m}^{2}$ year for a building with a Form Factor $<=0.5$ to $114.90 \mathrm{kWh} / \mathrm{m}^{2}$ year for a building with a Form Factor $<1.5$.

\subsection{Experimental plan}

In order to measure the air-tightness of these buildings, it was used the Minneapolis Blower Door-Model 4, DG-70o.

As described in the Operation manual of the equipment (27), "the Blower Door consists of a powerful, calibrated fan that is temporarily sealed into an exterior doorway. The fan blows air into or out of the building to create a slight pressure difference between inside and outside. This pressure difference forces air through all holes and penetrations in the exterior envelope. By simultaneously measuring the air flow through the fan and its effect on the air pressure in the building, the Blower Door system measures the airtightness of the entire building envelope".

Several airtightness measurements were carried out in the models M1 and M2, following an experimental schedule (Table 2) delineated to analyse the different doors and windows performance, specifying the placement of the blower door fan, and the doors needed to be sealed in order to extract (depressurization) or introduce (pressurization) air into the studied dwelling until a negative or positive pressure of 50 $\mathrm{Pa}$ (28) (29).

All measurements were performed in July 2012. The temperature and air conditions measured for the experimental are presented in Table 3 .

Table 2. Experimental schedule

\begin{tabular}{|l|c|c|c|c|}
\hline Experiment & Room & Blower Door & Sealed Doors & Analyzed Window / Door \\
\hline E.1 - M.1 & R.1+R.2+Ba.1 & D.05 & D.01; D.02 & Sw.1 \\
\hline E.2 - M.1 & R.2 & D.06 & D.01; D.02 & D.04 \\
\hline E. - M.1 & R.3 & D.07 & D.05; D.09 & Cw.1 \\
\hline E.4-M.1 & R.4 & D.08 & D.09 & Cw.2 \\
\hline E.5-M.1 & R.5 & D.13 & D.10;D.11 & D.12 \\
\hline E.6-M.1 & R.6 & D.14 & - & Sw.3 \\
\hline E.7-M.1 & R.7 & D.16 & D.15 & Sw.4 \\
\hline & & & & Cw.3 \\
\hline E.8 - M.2 & R.8 & D.18 & D.17 & \\
\hline
\end{tabular}

* Doors D.o3 and D.o4 were left widely open

Table 3. Temperature and air conditions

\begin{tabular}{|l|c|c|c|c|c|c|c|c|}
\hline \multicolumn{1}{|c|}{ Experiment } & E1 & E2 & E3 & E4 & E5 & E6 & E7 & E8 \\
\hline Inside temperature $\left({ }^{\circ} \mathrm{C}\right)$ & 24.5 & 24 & 27.1 & 27.5 & 24.2 & 24.1 & 24.5 & 23 \\
\hline Outside temperature $\left({ }^{\circ} \mathrm{C}\right)$ & 27.1 & 27.3 & 28.8 & 29.4 & 25.9 & 26.3 & 27 & 25.3 \\
\hline Barometric Pressure $(\mathrm{Pa})$ & 101325 & 101325 & 101325 & 101325 & 101325 & 101325 & 101325 & 101325 \\
\hline Wind speed $(\mathrm{m} / \mathrm{s})$ & 5.2 & 4 & 4.5 & 5 & 5.1 & 4.6 & 5 & 5 \\
\hline Wind direction & $\mathrm{NW}$ & $\mathrm{NW}$ & $\mathrm{NW}$ & $\mathrm{NW}$ & $\mathrm{NW}$ & $\mathrm{NW}$ & $\mathrm{NW}$ & NW \\
\hline
\end{tabular}


Table 4. Dwelling characteristics and results of the airflow measurements

\begin{tabular}{|c|c|c|c|c|c|c|c|c|}
\hline \multirow[b]{2}{*}{ Experiment } & \multirow{2}{*}{$\begin{array}{l}\text { Internal } \\
\text { Volume } \\
\quad\left(\mathbf{m}^{3}\right)\end{array}$} & \multirow{2}{*}{$\begin{array}{c}\text { Net Floor } \\
\text { Area } \\
\left(\mathbf{m}^{2}\right)\end{array}$} & \multirow{2}{*}{$\begin{array}{c}\text { Envelope } \\
\text { Area } \\
\left(\mathbf{m}^{2}\right)\end{array}$} & \multirow[b]{2}{*}{$\begin{array}{c}\text { Façade } \\
\text { Orientation }\end{array}$} & \multicolumn{4}{|c|}{ Results } \\
\hline & & & & & $\begin{array}{c}V_{50} \\
\left(m^{3} / h\right)\end{array}$ & $\underset{\left(\mathbf{A C H}_{50}^{\mathbf{H}}\right)}{\mathbf{n}}$ & $\begin{array}{c}W_{50} \\
\left(m^{3} / \mathbf{m}^{2} h\right)\end{array}$ & $\begin{array}{c}\mathbf{q}_{50} \\
\left(\mathbf{m}^{3} / \mathbf{m}^{2} \mathbf{h}\right)\end{array}$ \\
\hline E.1 & $123 \cdot 33$ & 36.82 & 12.12 & W & 1885 & 15.28 & 51.20 & 155.53 \\
\hline E. 2 & 59.29 & 17.54 & 8.18 & $\mathrm{~W}$ & 1296 & 21.86 & 73.89 & 158.44 \\
\hline E. 3 & 108.50 & 32.10 & 24.30 & $\mathrm{O}$ & 4059 & 37.41 & 126.45 & 167.02 \\
\hline E.4 & 51.21 & 15.15 & 14.77 & $\mathrm{O}$ & 1984 & 38.74 & 130.96 & 134.32 \\
\hline E. 5 & 30.57 & 8.94 & 6.70 & $\mathrm{~W}$ & 799 & 26.13 & 89.37 & 119.20 \\
\hline E.6 & 57.46 & 16.80 & 12.55 & $\mathrm{O}$ & 882 & $15 \cdot 35$ & 52.50 & 70.28 \\
\hline E.7 & 45.00 & 15.15 & 12.98 & $\mathrm{O}$ & 3270 & 72.67 & 215.84 & 251.95 \\
\hline E. 8 & 42.76 & 15.55 & 8.80 & $\mathrm{~S}$ & 6184 & 144.62 & 397.68 & 702.73 \\
\hline
\end{tabular}

\subsection{Parameters to be analysed}

\subsubsection{Defined by EN 13829 (30)}

- V5o $\left(\mathrm{m}^{3} / \mathrm{h}\right)$, air leakage rate at 50 Pascals,

- n50 air change rate at 50 Pascals, which expresses the value of the rate in relation to volume $\left(\mathrm{ACH}_{50}\right)$.

- w50 expresses the relationship between the air leakage rate and the floor area $\left(\mathrm{m}^{3} / \mathrm{hm}^{2}\right)$,

- q50 expresses the relationship between the air leakage rate and the entire envelope area $\left(\mathrm{m}^{3} / \mathrm{hm}^{2}\right)$

\subsubsection{Parameters not defined by EN 13829}

- Air leakage rate by unit of window area at $50 \mathrm{~Pa}$, h50, or the relationship between $\mathrm{V}_{50}$ and the size of the openings, $\mathrm{AH}$. This parameter provides information on infiltrations through the surface unit of openings, which is where most infiltrations occur $\left(\mathrm{m}^{3} / \mathrm{hm}^{2}\right)$.

- Air leakage rate by perimeter of window at $50 \mathrm{~Pa}, \mathrm{p} 50$, or the relationship between $\mathrm{V}_{50} \mathrm{O}$ and the perimeter of the openings (WP) $\left(\mathrm{m}^{3} / \mathrm{hm}\right)$.

- Air leakage rate by unit of façade area at $50 \mathrm{~Pa}, \mathrm{f} 50$, or the relationship between $\mathrm{V}_{50}$ and the area of the façade. This parameter provides information on infiltration through the surface unit of the entire façade, main element of the envelope through which infiltration occurs.

\section{RESULTS}

\subsection{Obtained data}

The data obtained in the experiments was incorporated into a Microsoft Excel spread sheet in order to analyse them in conjunction with the morphological characteristics of each room and window studied (Table 4).

For standard equipment, uncertainty in determining the various parameters that may be obtained with this test are below $11 \%$ in most cases (Table 5).

\subsection{Results interpretation}

One of the first steps in order to examine the data obtained was to relate the $\mathrm{ACH}_{50}$ results obtained for each window with the respective façade morphological characteristics, as presented in Table 6.
Table 5. Accuracy of the experiments

\begin{tabular}{|l|c|}
\hline Accuracy of the device to measure airflow rate & $+/-4 \%$ \\
\hline Accuracy building pressure & $+/-3 \%$ \\
\hline Uncertainty because of wind & $+/-1 \%$ \\
\hline $\begin{array}{l}\text { Uncertainty barometric pressure (standard or } \\
\text { measured) }\end{array}$ & $+/-5 \%$ \\
\hline $\begin{array}{l}\text { Uncertainty leaving out a depressurazition or } \\
\text { pressurazition }\end{array}$ & $+/-7 \%$ \\
\hline Uncertainty reference values & $+/-5 \%$ \\
\hline Random error of the airflow rate & $+/-1 \%$ \\
\hline Total in the experiment & $+/-11 \%$ \\
\hline
\end{tabular}

It was calculated the ratio (WRpa) between each window leakable perimeter (Wp) and respective window area (Wa) as well as the Window to Wall Ratio (WWR), considering these as two possible determinant variables in the results obtained.

The mean value achieved of $46.51 \mathrm{ACH}_{50}$ is superior to all the registered data excluding for windows Sw.4 and Cw.3, being the median value of $31.77 \mathrm{ACH}_{50}$.

By calculating the coefficient of variation (CV), it is possible to determine the relevance of the standard deviation (S) and what it indicates about the sample. The closer the CV is to o, the greater the uniformity of data. The closer the CV is to 1 , the greater the variability of the data.

Although it's clear the variability of the $\mathrm{ACH}_{50}$ results of this sample $(\mathrm{CV}=0.94)$, by checking the individual Standard Score (Z), otherwise known as the number of Standard Deviations a data is to the Mean, it's recognizable as expected, that the Window Cw.3 of Model M2 $(Z=2.24)$ can only be considered as an example of the $\mathrm{ACH}_{50}$ values obtained for an inhabited house with some recognizable cracks in the building elements.

On the other hand, Sw.1 and Sw.3 of Model M1 presented the second higher $\mathrm{Z}$ value (0.71) while had registered the lowest values of $\mathrm{ACH}_{50}, 15.28$ and 15.35 respectively. The window Sw.4, geometrically equivalent to Sw.3 and with a $\mathrm{Z}$ value of 0.47 , registered the second highest value of $\mathrm{ACH}_{50}$.

Due to the large difference of the value obtained in Cw.3 (4.5 times the mean value of the remaining $7-32.49 \mathrm{ACH}_{50}$ ), this element of the sample can clearly be considered as an "outlier”. An outlying observation, or outlier, is one that appears to 
Table 6. $\mathrm{ACH}_{5} \mathrm{O}$ results comparison with façade characteristics

\begin{tabular}{|c|c|c|c|c|c|c|c|c|c|c|c|c|}
\hline \multirow[b]{2}{*}{ Ensayo } & \multicolumn{4}{|c|}{ Window } & \multirow{2}{*}{$\begin{array}{c}\text { Envelope } \\
\text { Area } \\
\left(\mathbf{m}^{2}\right)\end{array}$} & \multirow[b]{2}{*}{$\begin{array}{c}\text { WWR } \\
\text { (\%) }\end{array}$} & \multirow[b]{2}{*}{$\begin{array}{l}\operatorname{ACH}_{50} \\
(1 / h)^{\circ}\end{array}$} & \multirow[b]{2}{*}{$\begin{array}{c}\text { ACH5o } \\
\text { Standard } \\
\text { Score }\end{array}$} & \multicolumn{4}{|c|}{ Ratio } \\
\hline & Ref. & $\begin{array}{c}\text { Wa } \\
\left(\mathrm{m}^{2}\right)\end{array}$ & $\begin{array}{l}\text { Wp } \\
\text { (ml) }\end{array}$ & $\underset{\left(\mathbf{m l} / \mathbf{m}^{2}\right)}{\text { Wrpa }}$ & & & & & $\underset{\mathbf{W a}}{\mathbf{A C H}_{50}} /$ & $\underset{\mathbf{W} \mathbf{p}}{\mathbf{A C H}_{50}} /$ & \begin{tabular}{c|}
$\mathbf{A C H}_{55} /$ \\
Envelope \\
Area
\end{tabular} & $\underset{\text { WWR }}{\mathbf{A C H}_{50} /}$ \\
\hline E.1 & Sw.1 & 7.29 & 14.40 & 1.97 & 12.12 & 60 & 15.28 & -0.71 & 2.10 & 1.06 & 1.26 & 0.25 \\
\hline E. 6 & Sw.3 & 4.22 & 7.84 & 1.86 & 12.55 & 34 & $15 \cdot 35$ & -0.71 & 3.63 & 1.96 & 1.22 & 0.46 \\
\hline E.7 & Sw.4 & 4.22 & 7.84 & 1.86 & 12.98 & 33 & 72.67 & 0.60 & 17.20 & 9.27 & 5.60 & 2.23 \\
\hline E. 2 & D.04 & 3.51 & 8.36 & 2.38 & 8.18 & 43 & 21.86 & -0.56 & 6.24 & 2.61 & 2.67 & 0.51 \\
\hline E. 5 & D.12 & 3.51 & 8.36 & 2.38 & 6.70 & 52 & 26.13 & -0.47 & 7.45 & 3.13 & 3.90 & 0.50 \\
\hline E. 3 & Cw.1 & 13.45 & $35 \cdot 32$ & 2.63 & 24.30 & 55 & 37.41 & -0.21 & 2.78 & 1.06 & 1.54 & 0.68 \\
\hline E. 4 & Cw.2 & 6.73 & 17.66 & 2.63 & 14.77 & 46 & 38.74 & -0.18 & 5.76 & 2.19 & 2.62 & 0.85 \\
\hline E. 8 & Cw. 3 & 2.42 & 11.00 & 4.55 & 8.80 & 28 & 144.62 & 2.24 & 59.76 & 13.15 & 16.43 & 5.26 \\
\hline \multicolumn{2}{|c|}{ Median } & 4.22 & 9.68 & 2.38 & 12.34 & 44.20 & 31.77 & & 6.00 & 2.40 & 2.65 & 0.59 \\
\hline \multicolumn{2}{|c|}{ Mean (M) } & 5.67 & 13.85 & 2.53 & 12.55 & 43.74 & 46.51 & & 13.12 & 4.30 & 4.41 & 1.34 \\
\hline \multicolumn{2}{|c|}{ St Dev (S) } & 3.55 & 9.38 & 0.87 & 5.49 & 11.79 & 43.79 & & 19.44 & 4.44 & 5.08 & 1.70 \\
\hline \multicolumn{2}{|c|}{$\mathrm{CV}=\mathrm{S} / \mathrm{M}$} & 0.63 & 0.68 & 0.35 & 0.44 & 0.27 & 0.94 & & 1.48 & 1.03 & 1.15 & 1.27 \\
\hline
\end{tabular}

Table 7. Comparison between two similar dwellings and airtightness values

\begin{tabular}{|c|c|c|c|c|c|c|}
\hline \multirow[b]{2}{*}{ Experiment } & \multirow{2}{*}{$\begin{array}{c}\text { Internal } \\
\text { Volume } \\
\left(\mathbf{m}^{3}\right)\end{array}$} & \multirow{2}{*}{$\begin{array}{c}\text { Net Floor } \\
\text { Area } \\
\left(\mathbf{m}^{2}\right)\end{array}$} & \multirow{2}{*}{$\begin{array}{c}\text { Envelope } \\
\text { Area } \\
\left(\mathbf{m}^{2}\right)\end{array}$} & \multicolumn{3}{|c|}{ Results } \\
\hline & & & & $\begin{array}{c}V_{50} \\
\left(\mathrm{~m}^{3} / h\right)\end{array}$ & $\begin{array}{c}\mathbf{W}_{5 o} \\
\left(\mathrm{~m}^{3} / \mathbf{m}^{2} h\right)\end{array}$ & $\underset{\left(\mathrm{m}^{3} / \mathbf{m}^{2} h\right)}{\mathbf{q}_{50}}$ \\
\hline Sw.3 & 57.46 & 16.80 & 12.55 & 882.00 & 52.50 & 106.57 \\
\hline Sw.4 & 45.00 & 15.15 & 12.98 & 3270 & 215.84 & 251.95 \\
\hline
\end{tabular}

deviate markedly from other members of the sample in which it occurs. This is particularly important due to the number of data obtained. It is also legitimate to conclude that both Sw.4 (2.8 times the mean value of the remaining 6) and its surrounding envelope area are in a worst state of conservation, also confirmed by comparing the identical morphological characteristics of the respective dwellings of Sw.3 and Sw.4 (windows geometrically equals) and the airtightness values measured (Table 7) and also by being independent fractions of the same building, with different owners. The addition of an interior roller blind may as well cause this discrepancy, due to a deficient sealing when applied.

This interpretation is also confirmed by the differences obtained between the mean value (M) and both the median and standard deviation values, considering the exclusion of the Cw.3 and Sw.4 observations (Table 8). A normal distribution of a sample occurs as closer are the mean and median values (93\%) and with a lower difference between mean and standard deviation values (40\%), as expressed in Table 8.

Table 8. Differences obtained between the mean, median and standard deviation values, excluding Cw.3 and Sw.4

\begin{tabular}{|l|c|c|}
\hline \multicolumn{3}{|c|}{ Difference } \\
\hline Mean (M) - Median & 1.80 & $93 \%$ \\
\hline Mean (M) - Standard Deviation (S) & 15.43 & $40 \%$ \\
\hline
\end{tabular}

Analysing the relation between these $\mathrm{ACH}_{50}$ results (excluding both Cw.3 and Sw.4) with the respective envelope area (Figure 8), window area (Figure 9), window frame perimeter (Figure 10) and window wall ratio (Figure 11), it's recognizable that they do not present any data correlation.

\subsection{Results potential development}

However, reanalysing the results obtained, it is possible to recognize a potential relation between the infiltration rate performance and the windows typology, which is characterized by the ratio between its leakable perimeter and area (Figure 12).

By calculating the correlation coefficient (R) within this sample, the value of 0.93 was obtained. This coefficient measures the strength and the direction of a linear relationship between two variables. A correlation greater than 0.8 is generally described as strong positive one. Due to the dimension of the sample it is only possible to characterize this value as a potential correlation.

\section{CONCLUSIONS}

With the number of measurements performed, no correlation was established between the air infiltration rate and the morphological absolute dimensions of the building, such as envelope area, window area or window perimeter.

There is a high dispersion between zones in the same building, in the same plant, with the same envelope and the same types of windows (usually the elements which have the greatest influence on the air-tightness, by the permeability of the window itself and respective sealing's to wall). When comparing geometrical similar types of dwellings but with different states of conservation, it is possible to obtain a 4 times increase on the air leakage. 


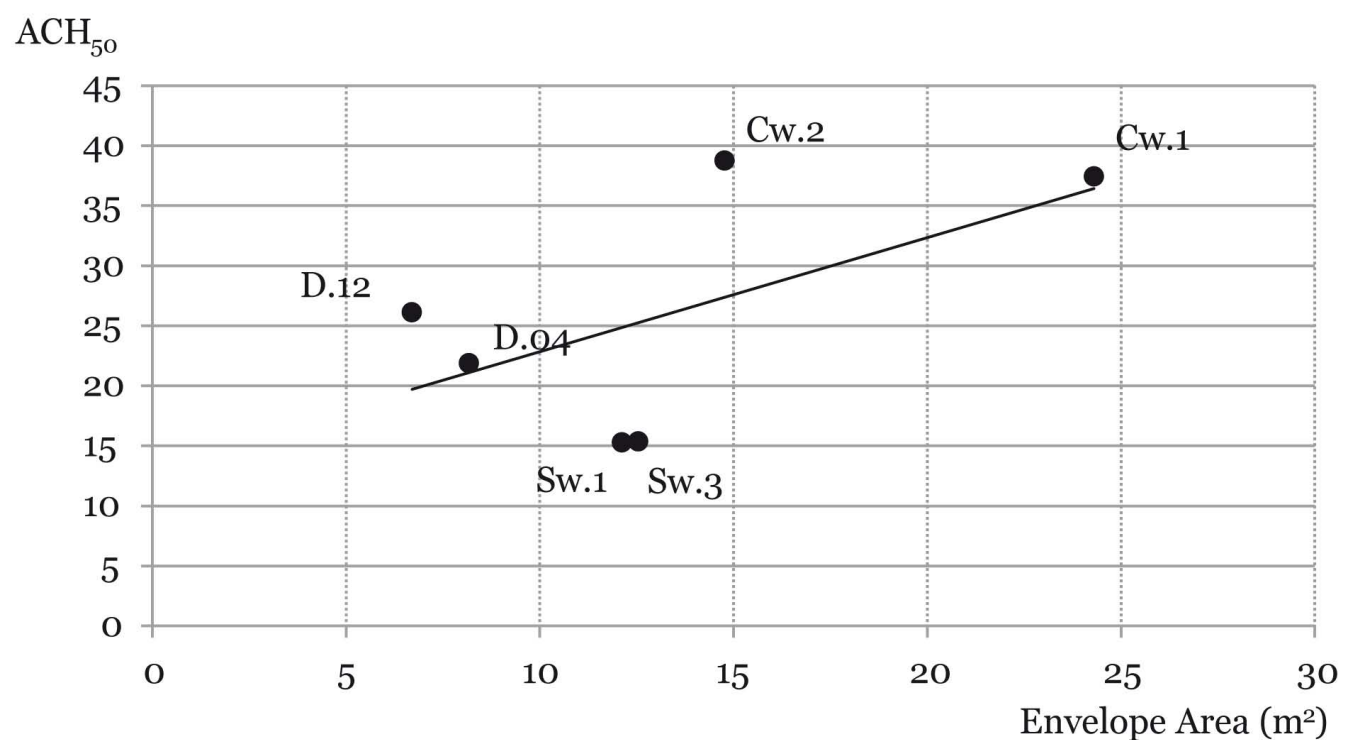

Figure 8. Correlation between envelope area and $\mathrm{ACH}_{50}$

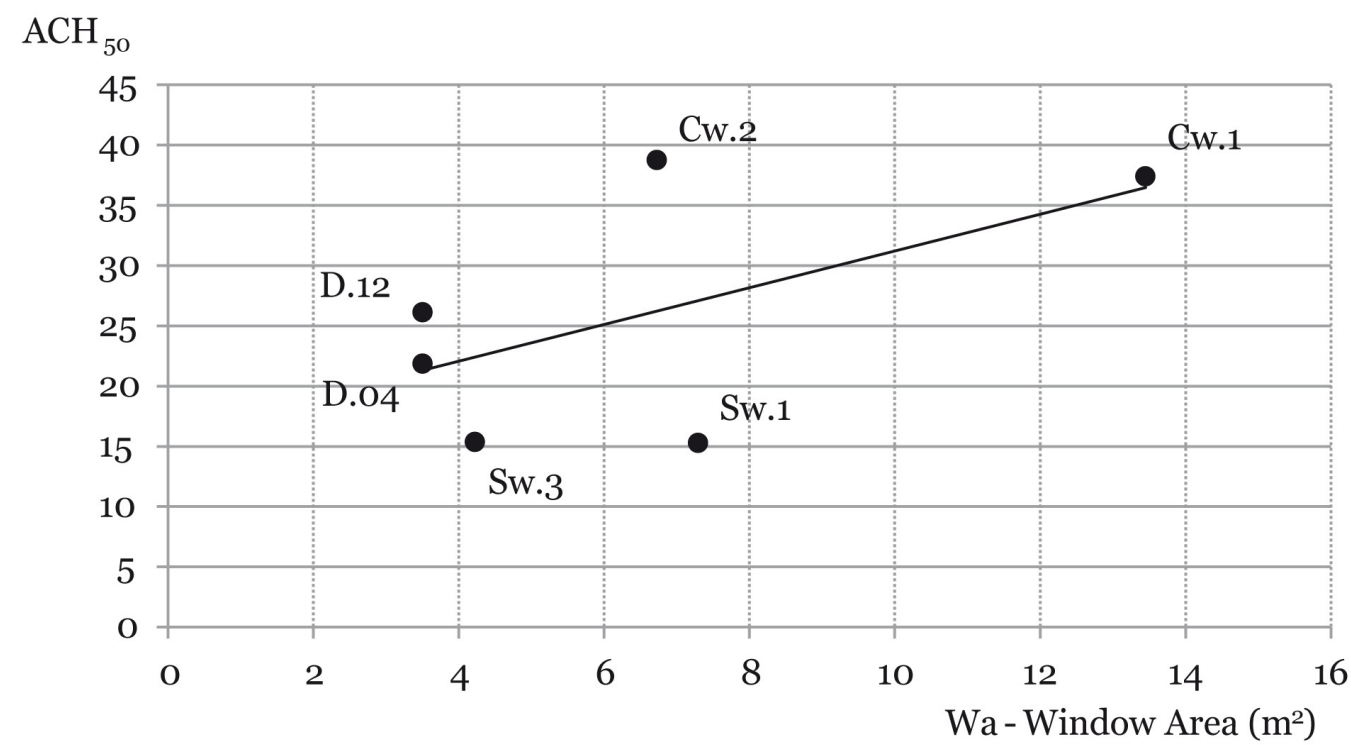

Figure 9. Correlation between window area and $\mathrm{ACH}_{50}$

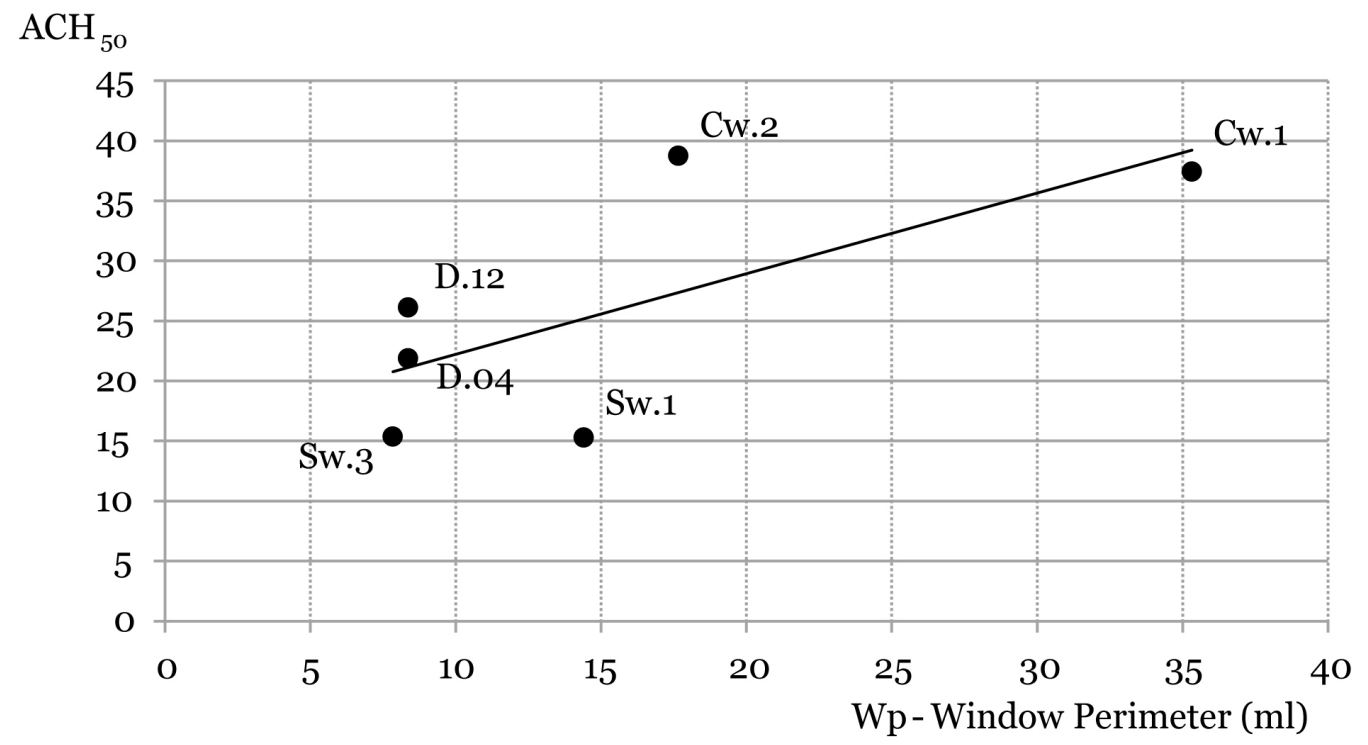

Figure 10. Correlation between window perimeter and $\mathrm{ACH}_{50}$ 


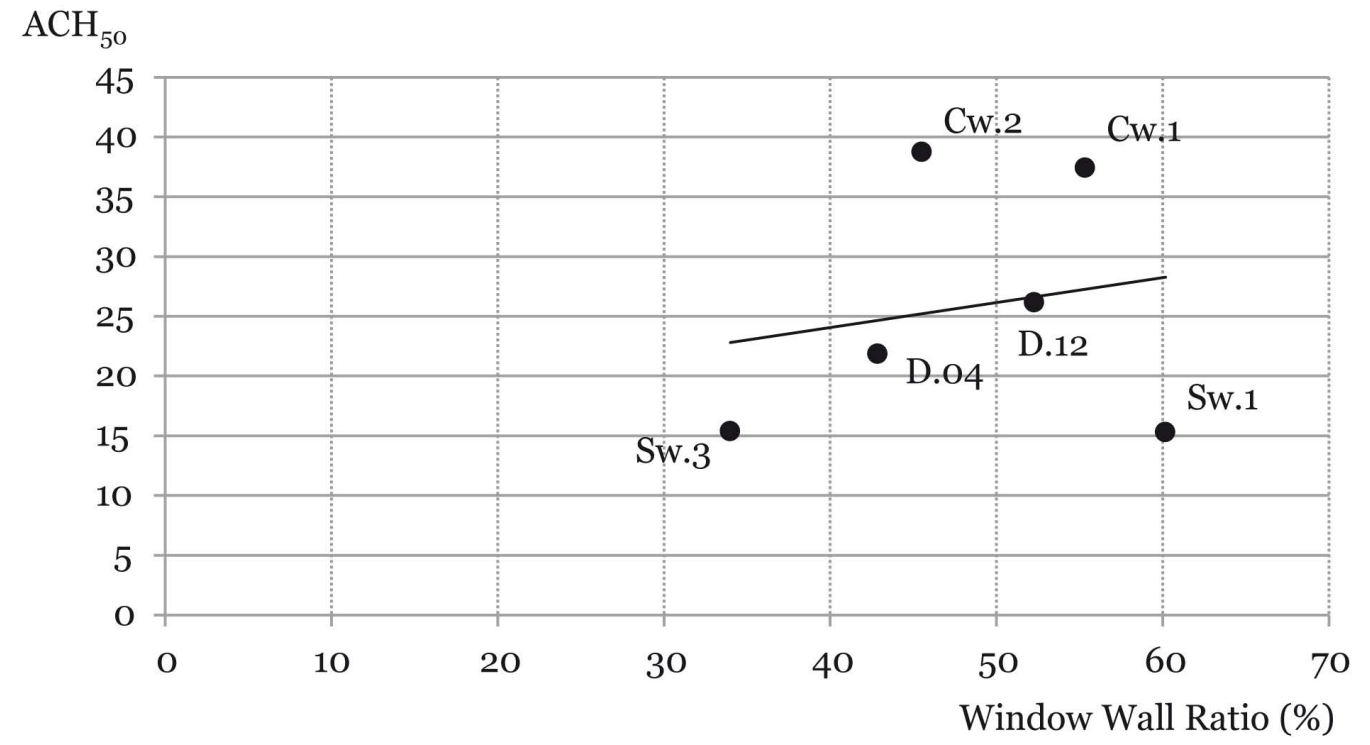

Figure 11. Correlation between window wall ratio and $\mathrm{ACH}_{50}$

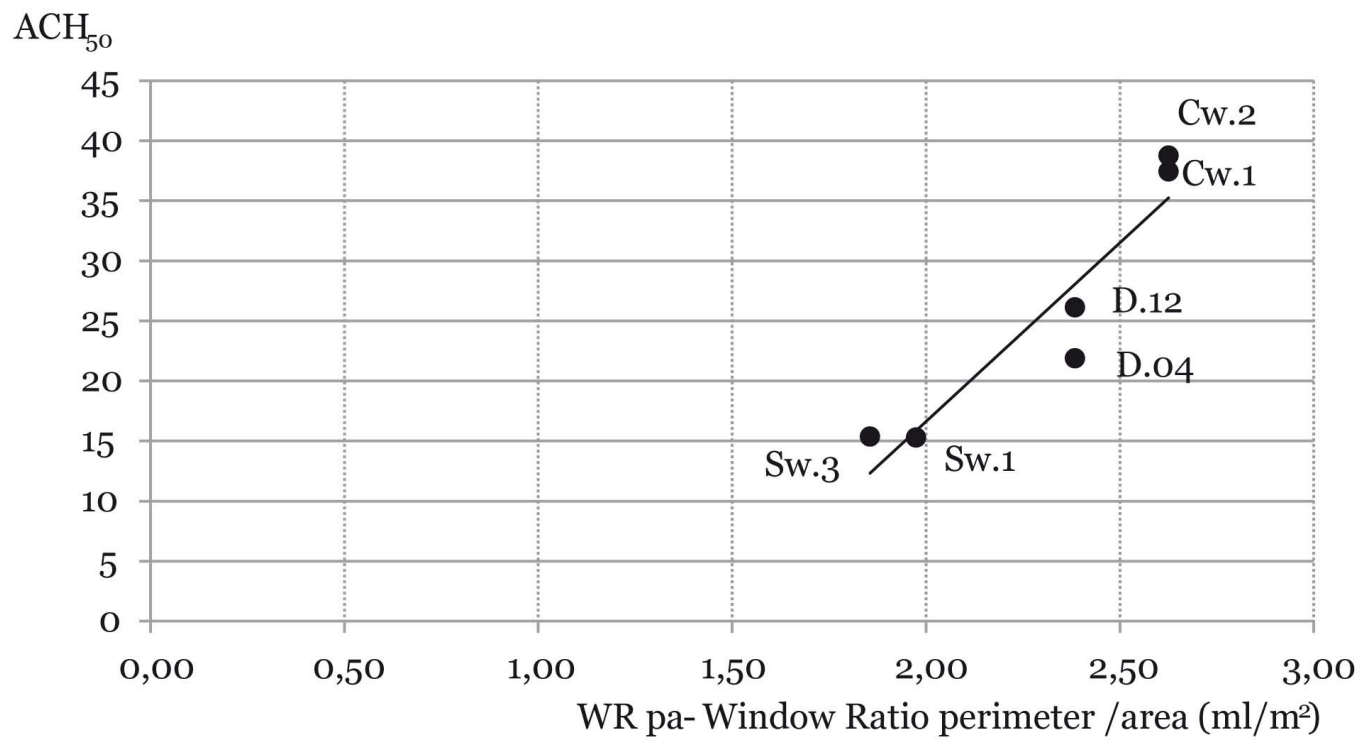

Figure 12. Correlation between window ratio perimeter/area and $\mathrm{ACH}_{50}(\mathrm{R}=0.93)$

Nevertheless, the proportional relation between these morphological elements may be responsible for determining an $\mathrm{ACH}_{50}$ variation such as the windows typology, defined by the ratio between its perimeter and area.

This investigation shows that control airtightness protocols are required either for new constructions or for retrofitting of existing buildings, being quite determinant the details of the elements joints and the construction phase. This is particular opportune for these historic buildings due to its most common state of conservation.

A primary measure to ensure this performance enhancement is to reduce direct drafts from air leakage to minimum val- ues when the building is not occupied, so to avoid superficial humidity from condensation and enable its gradual increase when occupied, counting on adjustable airflow ventilation systems. One of the key procedures to accomplish this air leakage adjustment is precisely to upgrade the air infiltration rate of the windows' framing, avoiding any cracks in the window assembly. Succeeding this intervention we can as well improve the windows heat transmittance by adjusting the framing to a double glazed solution.

Given the importance of air tightness in thermal sensation and energy consumption, this is a crucial aspect to consider when defining retrofitting strategies, in a balance between patrimonial values and energy efficiency. 


\section{REFERENCES}

(1) CEN. (2007). EN 15251-Indoor environmental input parameters for design and assessment of energy performance of buildings addressing indoor air quality, thermal environment, lighting acoustics. European Committee for Standardization (CEN).

(2) De Luxán, M., Vázquez, M., Gómez, G., Román, E., Barbero, M. (2009). Actuaciones con criterios de sostenibilidad en la rehabilitación de viviendas en el centro de Madrid. Madrid: Empresa Municipal de Vivienda y Suelo del Ayuntamiento de Madrid.

(3) WHC. (2006). State of Conservation of World Heritage Properties in Europe: Section II. http://whc.unesco.org/archive/ periodicreporting/EUR/cycleo1/section2/755-summary.pdf

(4) SRU. (2010). Importância Energética de Envolvente dos Edificios. In Reabilitação de Edifícios do Centro Histórico do Porto: Guia de Termos de Referência para o Desempenho Energético-Ambiental, (p. 11). Porto: Porto Vivo, SRUSociedade de Reabilitaçao Urbana de Baixa Portuense, S.A.

(5) Parlamento Europeu. (2002, 16 de Dezembro). Directiva 2002/91/CE do Parlamento Europeu e do Conselho relativa ao desempenho energético dos edifícios. Jornal Oficial, nº L 001: 0065-0071

(6) Ministério das obras públicas, transportes e comunicaçoes. (2006, 4 de Abril). Decreto-Lei n. ${ }^{\circ} 80 / 2006$ - Regulamento das Características de Comportamento Térmico de Edifícios (RCCTE). Diário da República, nº67: 2468-2513.

(7) Ministério das obras públicas, transportes e comunicaçoes. (2006, 4 de Abril). Decreto-Lei n. ${ }^{\circ} 79 / 2006$ - Regulamento dos Sistemas Energéticos de Climatização em Edifícios (RSECE). Diário da República, nº67: 2416-2468.

(8) Ministério da Economia e da Inovaçao. (2006, 4 de Abril) Decreto-Lei n. ${ }^{0}$ 78/ 2006 - Sistema Nacional de Certificação Energética e da Qualidade do Ar Interior nos Edifícios (SCE). Diário da República, nº67: 2411-2415.

(9) Alves, S., Sendra, J.J. (2012). Rehabilitation and Energy efficiency - Methodological strategies for the Historic Centre of Oporto. In Heritage 2012 - Proceedings of the $3^{\text {rd }}$ International Conference Heritage and Sustainable Development. (p. 395). Portugal: Green Lines Institute.

(10) Freire, R. Z., Mazuroski, W., Abadie, M. O., Mendes, N. (2011). Capacitive effect on the heat transfer through building glazing systems. Applied Energy 88(12): 4310-4319, doi: http://dx.doi.org/10.1016/j.apenergy.2011.04.006.

(11) Saridar, S., Elkadi, H. (2002) The impact of applying recent façade technology on daylighting performance in buildings in eastern Mediterranean. Building and Environment 37(11): 1205 - 1212, doi: http://dx.doi.org/10.1016/So3601323(01)00095-6.

(12) Papadopoulos, A.M., Theodosiou, T., Karatzas, K. (2002). Feasibility of energy saving measures in urban buildings - The impact of energy prices and the acceptable pay back criterion. Energy and Buildings 34(5): 455-466, doi: http://dx.doi. org/10.1016/So378-7788(01)o0129-3.

(13) Tommerup, H., Svendsen, S. (2006). Energy savings in Danish residential building stock. Energy and Buildings, 38(6): 618-626, doi: http://dx.doi.org/10.1016/j.enbuild.2005.08.017.

(14) Domínguez, S., Sendra, J.J., León, A.L., Esquivias, P. M. (2012). Towards an energy demand reduction in social housing buildings: Envelope system optimization strategies. Energies, 5(7): 2263-2287, doi: http://dx.doi.org/10.3390/ en5072263.

(15) Binamu, A. (2002). Integrating building design properties "air tightness" and ventilation heat recovery for minimum heating energy consumption in cold climates. Dissertation. Tampere: University of Technology.

(16) Jokisalu, J., Kurnitski, J. (2002). Simulation of energy consumption in typical Finnish detached house. Report B74. Helsinki: University of Technology, HVAClaboratory.

(17) Emmerich S.J., Persily A.K. (1998). Energy impacts of infiltration and ventilation in US office buildings using multi-zone airflow simulation. In Proceedings of ASHRAE IAQ and energy 98 conference, (pp. 191-203). New Orleans, LA, USA.

(18) Becker, R. (1979). Window air tightness and its influence on energy saving and minimum required ventilation. Building and Environment, 14(3): 157-165, doi: http://dx.doi.org/10.1016/0360-1323(79)90034-9.

(19) Etheridge, D.W., Stanway, R.J. (1988). A parametric study of ventilation as a basis for design. Building and Environment, 23(2): 81-93, doi: http://dx.doi.org/10.1016/0360-1323(88)90022-4.

(20) Feustel, H. (1990). Measurements of Air Permeability in Multizone Buildings. Energy and Buildings, 14(12): 103-116, doi: http://dx.doi.org/10.1016/0378-7788(90)90030-M.

(21) Kalamees, T. (2007). Air tightness and air leakages of new lightweight single-family detached houses in Estonia. Building and Environment, 42(6): 2369-2377, doi: http://dx.doi.org/10.1016/j.buildenv.2006.06.001.

(22) Pinto, M. Viegas, J. de Freitas, V.P. (2011). Air permeability measurements of dwellings and building components in Portugal. Building and Environment, 46(12): 2480-2489, doi: http://dx.doi.org/10.1016/j.buildenv.2011.06.009.

(23) Alfano, F.R., Dell'Isola, M., Ficco, M., Tassini, F. (2012). Experimental analysis of air tightness in Mediterranean buildings using the fan pressurization method. Building and Environment, 53: 16-25, doi: http://dx.doi.org/10.1016/j.buildenv.2011.12.017.

(24) Dimitroulopoulou, C. (2012). Ventilation in European dwellings: a review. Building and Environment, 47: 109-125, doi: http://dx.doi.org/10.1016/j.buildenv.2011.07.016.

(25) Meiss, A., Feijó, J. (2011). Influencia de la ubicación de las aberturas en la eficiencia de la ventilación en viviendas. Informes de la Construcción, 63 (522): 53-6o, doi: http://dx.doi.org/10.3989/ic.10.001.

(26) Fernandes, E.O. (2011). HOPE project 2004: measurements reports HAB2 and HAB3.

(27) Minneapolis Blower Door ${ }^{\mathrm{TM}}$. (2008). Operation Manual for Model 3 and Model 4 Systems. Minneapolis: The Energy Conservatory. 
(28) Fernández-Agüera, J., Sendra, J.J., Domínguez, S. (2011). Protocols for measuring the airtightness of multi-dwelling units in Southern Europe. In Proceedings of the 2011 International Conference on Green Buildings and Sustainable Cities. Bologna, Italy.

(29) Fernández-Agüera, J., Suárez, R., Heiselber, P. (2012). Influence of improvement of airtightness on energy retrofit of social Housing, a case study in a Mediterranean climate. In 33rd AIVC Conference and 2nd TightVent Conference. Copenhague, Denmark.

(30) CEN. (2002). EN 13829 - Thermal performance of buildings. Determination of air permeability of buildings. Fan pressurization method. (ISO 9972:1996, modified). European Committee for Standardization (CEN/TC89). 